University of Montana

ScholarWorks at University of Montana

$7-2008$

\title{
Effects of Native Species Diversity and Resource Additions on Invader Impact
}

John L. Maron

University of Montana - Missoula, john.maron@mso.umt.edu

Marilyn Marler

Follow this and additional works at: https://scholarworks.umt.edu/biosci_pubs

Part of the Biology Commons

Let us know how access to this document benefits you.

\section{Recommended Citation}

Maron, John L. and Marler, Marilyn, "Effects of Native Species Diversity and Resource Additions on Invader Impact" (2008). Biological Sciences Faculty Publications. 202.

https://scholarworks.umt.edu/biosci_pubs/202

This Article is brought to you for free and open access by the Biological Sciences at ScholarWorks at University of Montana. It has been accepted for inclusion in Biological Sciences Faculty Publications by an authorized administrator of ScholarWorks at University of Montana. For more information, please contact

scholarworks@mso.umt.edu. 


\section{Effects of Native Species Diversity and Resource Additions on Invader Impact}

John L. Maron ${ }^{*}$ and Marilyn Marler ${ }^{\dagger}$

Division of Biological Sciences, University of Montana, Missoula, Montana 59812

ABstract: Theory and empirical work have demonstrated that diverse communities can inhibit invasion. Yet, it is unclear how diversity influences invader impact, how impact varies among exotics, and what the relative importance of diversity is versus extrinsic factors that themselves can influence invasion. To address these issues, we established plant assemblages that varied in native species and functional richness and crossed this gradient in diversity with resource (water) addition. Identical assemblages were either uninvaded or invaded with one of three exotic forbs: spotted knapweed (Centaurea maculosa), dalmatian toadflax (Linaria dalmatica), or sulfur cinquefoil (Potentilla recta). To determine impacts, we measured the effects of exotics on native biomass and, for spotted knapweed, on soil moisture and nitrogen levels. Assemblages with high species richness were less invaded and less impacted than less diverse assemblages. Impact scaled with exotic biomass; spotted knapweed had the largest impact on native biomass compared with the other exotics. Although invasion depressed native biomass, the net result was to increase total community yield. Water addition increased invasibility (for knapweed only) but had no effect on invader impact. Together, these results suggest that diversity inhibits invasion and reduces impact more than resource additions facilitate invasion or impact.

Keywords: native plant diversity, invasibility, invader impact, exotic plants, resource addition.

Biological invasions have become a worldwide phenomenon, with barely an ecosystem left that is untouched by exotic species. Although the scale and impact of invasions are sobering, these very attributes provide an unprecedented opportunity to gain insight into fundamental issues in population and community ecology that would be difficult to explore in the absence of this large-scale perturbation (Sax et al. 2005; Callaway and Maron 2006).

* Corresponding author; e-mail: john.maron@mso.umt.edu.

† E-mail: marilyn.marler@mso.umt.edu.

Am. Nat. 2008. Vol. 172, pp. S18-S33. (C) 2008 by The University of Chicago. 0003-0147/2008/1720S1-42858\$15.00. All rights reserved.

DOI: $10.1086 / 588303$
One question of long-standing interest concerns whether communities possess particular attributes that may make them more or less susceptible to invasion (Elton 1958). This is a question of fundamental interest because invasions result in a novel type of community assembly. The question of whether assembly occurs via neutral processes or is constrained by the degree of niche overlap among established species has a bearing on both recent (Hubbell 2001; Tilman 2004) and older theories (MacArthur 1970).

Consistent with niche-based theory, one line of thinking is that community diversity should strongly influence community invasion. Theory predicts that resource preemption should increase as the diversity of a community increases (MacArthur 1970; Post and Pimm 1983; Case 1990; Tilman 2004), and thus, the susceptibility of communities to invasion should be a function of their diversity. Many small-scale experiments support this theory in that they have found (1) a negative relationship between plant diversity and invasibility (where invasibility is quantified as total invader biomass or total number of individuals that invade a community; Levine 2000; Naeem et al. 2000; Prieur-Richard et al. 2000; Symstad 2000; Dukes 2002; Kennedy et al. 2002; Fargione et al. 2003; van Ruijven et al. 2003; Zavaleta and Hulvey 2004) and (2) evidence for declining resource availability in more diverse assemblages (Kennedy et al. 2002; Fargione et al. 2003; Maron and Marler 2007).

An alternative line of thinking has been that inherent properties of communities are less important to invasion resistance than other factors. For example, Davis et al. (2000) proposed that fluctuations in resource availability, driven by disturbance or other factors, set community susceptibility to invasion (Davis et al. 2000; Davis and Pelsor 2001; Thomsen et al. 2006). Others have pointed to particular attributes of exotics in determining their ability to invade, either because they can access resources not available to natives (Holmes and Rice 1996; Dyer and Rice 1999) or because they exude allelopathic compounds that native plants do not have adaptations to defend against (Callaway and Aschehoug 2000; Callaway et al., 1998). 
While attributes of invaders, extrinsic factors, and intrinsic community characteristics have all been individually implicated in affecting invader success, what is unclear is (1) how these various factors compare in the strength of their individual effects, (2) whether they interact to influence invader success, and (3) the extent to which they mediate the impact that an invader has on a recipient community (Dukes 2002). In experimental systems where diversity, resource availability, or disturbance has been manipulated (reviewed by Levine et al. [2004]), invader impact typically has not been examined. Instead, the focus has been on determining how these manipulations influence invader abundance. Studies that have quantified invader impacts tend to come from highly invaded natural communities and often focus on the impact of invaders on ecosystem processes, such as nitrogen and water availability or fire frequency (Vitousek and Walker 1989; D'Antonio 2000; Gerlach 2000; Zavaleta 2000; Evans et al. 2001). However, since the impacts of exotics in these heavily invaded areas are often uniformly large, insight into the factors that produce variation in exotic impact is limited (Levine et al. 2003).

Determining the extent to which increasing diversity or resource availability can influence both invasibility and invader impact can shed light on several important issues. One of these concerns the scaling relationship between invasibility and impact. Some of the most devastating exotics possess novel function, and their impact may be fairly large even at relatively low density (Ehrenfeld 2003). This implies that the relationship between invader density and impact may not be linear but instead may be a threshold function. Alternatively, for many exotics, their success as invaders (and hence their biomass) may scale directly with their impact. However, since some invaders occur over a range of relatively low densities ("weak invaders" sensu Ortega and Pearson 2005) whereas others occur at moderate to extremely high density ("strong invaders"; Ortega and Pearson 2005), it is of interest to know how the scaling relationship between density and impact varies among invaders and why certain invaders have greater impacts than others. A second issue of importance concerns how exotics with large impacts affect overall community productivity. Due to their strong competitive effects, does invasion suppress overall community productivity? Or, because exotics themselves are highly productive, does the biomass they contribute to an assemblage outweigh the reductions they cause in native production? More generally, how might invasions change the often-found positive relationship between diversity and productivity (reviewed by Hooper et al. [2005])?

Determining the relationship between invasibility and the impact of invaders on native assemblages can also be beneficial to natural areas management. Managers often seek to decrease the negative impacts of exotics on natives. If invasibility and impact are synonymous, then managing to reduce exotic abundance will limit invader impacts. If native diversity limits invader impact, then restoring or maintaining this diversity might be a key to limiting invader impacts. However, if diversity has little effect on impact or if the relationship between exotic abundance and impact is not linear, then understanding where threshold effects occur and how these differ among exotics will be key to reducing invader impacts.

In previous work, we demonstrated that invasion by the widespread exotic forb, spotted knapweed (Centaurea maculosa), is strongly influenced by experimental manipulation of both native plant diversity and soil moisture (Maron and Marler 2007). Here, we build on these results in two important ways. First, we examine how native diversity and resource (water) supply and their interaction influence the impact of spotted knapweed on native assemblages. Invaders can impact native communities in several ways. They can directly reduce native plant biomass, and if these effects are severe and long-lasting, they can ultimately reduce local diversity. Mechanistically, they can deplete (or in the case of exotic $\mathrm{N}$-fixers, add) resources for natives, which can lead to declines in native performance. We explored effects of spotted knapweed on native plant biomass as well as on soil moisture and soil nitrogen levels. This, in combination with quantifying knapweed biomass, enabled us to determine (1) whether invader impacts on the biotic and abiotic environment scaled similarly across a gradient in native diversity and (2) whether resource supply influenced invader impact or interacted with native diversity to mediate impact. In isolation, increased resource availability can strongly facilitate invasion (Aerts and Berendse 1988; Hobbs and Huenneke 1992; Milchunas and Lauenroth 1995; Wedin and Tilman 1996; Davis and Pelsor 2001; Thomsen et al. 2006), but how resource availability affects invader impact is unclear. Increased resource availability could have large effects on impacts if it leads to dramatic increases in exotic biomass. Alternatively, if native plant biomass is increased as well, the net effect of resource supply on impact may be minimal. Whether the positive effects of resource supply in facilitating invasion (or enhancing invader impact) outweigh the relative negative effects of diversity in resisting invasion (or invader impact) remains to be seen. Another important question concerns how community attributes mediate the extent to which exotics impact the abiotic environment. We know that invaders can have large impacts on soil resources, such as soil nitrogen, and this can feed back and negatively influence native performance (Vitousek and Walker 1989). However, we do not know how community diversity mediates the magnitude of these feedbacks.

Second, we compare the ability of spotted knapweed to 
invade and affect assemblages to the impact of two other potent and very abundant exotic perennial forbs that can be dominant invaders in grasslands in the intermountain West, dalmatian toadflax (Linaria dalmatica) and sulfur cinquefoil (Potentilla recta; Sheley and Petroff 1999). Most studies of diversity-invasibility have experimentally staged invasions with only one exotic species (Dukes 2002; Zavaleta and Hulvey 2004; Rinella et al. 2007), used natives as surrogates for exotics (Knops et al. 1999; Lavorel et al. 1999; Symstad 2000; van Ruijven et al. 2003), staged invasions with seedlings rather than seeds (Prieur-Richard et al. 2000), or let assemblages become naturally invaded by many species (Kennedy et al. 2002; Fargione et al. 2003). We took a different approach, where we invaded with seeds of three exotics that differed in their functional attributes (phenology, rooting morphology, germination ecology, allelopathy). We then determined whether these exotics responded similarly and similarly impacted native assemblages when exposed to variation in native diversity and resource supply. We also examined whether the impact of each exotic species on native biomass differed after controlling for differences in its invasibility.

\section{Methods}

\section{Experimental Design}

In April-May 2003, we created 26 unique native perennial plant assemblages that varied in both species (one to 16 species) and functional richness (one to six functional groups). Twelve of these 26 assemblages were composed of mixes that varied in species and functional richness (table 1); results from these 12 are reported here. The remaining 14 assemblage types were monocultures of constituent native species used in mixes or exotics used to invade assemblages. Results from these monocultures will be reported elsewhere. Experimental assemblages were composed of plants that commonly co-occur in the grasslands of western Montana. Diversity in grasslands in the Missoula Valley averages 10.1 species $/ \mathrm{m}^{2}$ (range: $1-15$; M. Marler, unpublished data). We focus primarily on forb diversity (although not exclusively), since these species account for 1.5 times the biomass of grasses in the "grasslands" of western Montana (Mueggler and Stewart 1980). We chose plants that varied in the timing and depth of resource uptake because functional diversity in this regard can affect the amount of resources remaining for invaders (Fargione and Tilman 2005). The 16 species of plants we used belong to the following six functional groups: grasses, early-flowering forbs that branch with short rhizomes or stolons or at the root crown, midseason forbs with spreading rhizomes, midseason forbs with woody root crowns, very early-flowering ephemeral forbs with a shallow taproot, and late-season forbs with deep taproots (see table 2 for species names). If mixtures contained a subset of species from a particular functional group, species from that functional group were randomly assigned. In cases where different diversity treatments had identical species and functional richness (i.e., treatments 5 and 6; table 1), the treatments varied in the functional groups from which species were drawn. Diversity treatments with identical combinations of species and functional richness (e.g., treatments 2 vs. 3, 5 vs. 6 , etc.; table 1) varied in functional identity, which was chosen randomly. Each diversity treatment was crossed factorially with water addition or ambient water, and each treatment combination was replicated three times.

Starting in January 2003, we grew individual plants from locally collected seed in "conetainers" $(2.5 \mathrm{~cm} \times 16.5$ $\mathrm{cm}$; Stuewe and Sons, Corvallis, OR) in a greenhouse. In April-May 2003, we transplanted these individuals into

Table 1: Combination of species richness and functional richness used in experimental assemblages

\begin{tabular}{|c|c|c|c|}
\hline Treatment & Community composition & Species richness & Functional richness \\
\hline 1 & $\mathrm{G}_{1 \mathrm{a}} \mathrm{G}_{1 \mathrm{~b}}$ & 2 & 1 \\
\hline 2 & $\mathrm{G}_{1 \mathrm{a}} \mathrm{G}_{1 \mathrm{~b}} \mathrm{~F}_{2 \mathrm{a}} \mathrm{F}_{2 \mathrm{~b}} \mathrm{~F}_{2 \mathrm{c}}$ & 5 & 2 \\
\hline 3 & $\mathrm{G}_{1 \mathrm{a}} \mathrm{G}_{1 \mathrm{~b}} \mathrm{~F}_{3 \mathrm{a}} \mathrm{F}_{3 \mathrm{~b}} \mathrm{~F}_{3 \mathrm{c}}$ & 5 & 2 \\
\hline 4 & $\mathrm{G}_{1 \mathrm{a}} \mathrm{G}_{1 \mathrm{~b}} \mathrm{~F}_{2 \mathrm{x}} \mathrm{F}_{3 \mathrm{x}} \mathrm{F}_{3 \mathrm{y}}$ & 5 & 3 \\
\hline 5 & $\mathrm{G}_{1 \mathrm{a}} \mathrm{G}_{1 \mathrm{~b}} \mathrm{~F}_{1 \mathrm{x}} \mathrm{F}_{1 \mathrm{y}} \mathrm{F}_{2 \mathrm{x}} \mathrm{F}_{2 \mathrm{y}}$ & 6 & 3 \\
\hline 6 & $\mathrm{G}_{1 \mathrm{a}} \mathrm{G}_{1 \mathrm{~b}} \mathrm{~F}_{2 \mathrm{x}} \mathrm{F}_{2 \mathrm{y}} \mathrm{F}_{3 \mathrm{x}} \mathrm{F}_{3 \mathrm{y}}$ & 6 & 3 \\
\hline 7 & $\mathrm{G}_{1 \mathrm{a}} \mathrm{G}_{1 \mathrm{~b}} \mathrm{~F}_{1 \mathrm{x}} \mathrm{F}_{1 \mathrm{y}} \mathrm{F}_{2 \mathrm{x}} \mathrm{F}_{3 \mathrm{x}}$ & 6 & 4 \\
\hline 8 & $\mathrm{G}_{1 \mathrm{a}} \mathrm{G}_{1 \mathrm{~b}} \mathrm{~F}_{1 \mathrm{x}} \mathrm{F}_{2 \mathrm{x}} \mathrm{F}_{2 \mathrm{y}} \mathrm{F}_{3 \mathrm{x}}$ & 6 & 4 \\
\hline 9 & $\mathrm{G}_{1 \mathrm{a}} \mathrm{G}_{1 \mathrm{~b}} \mathrm{~F}_{1 \mathrm{x}} \mathrm{F}_{1 \mathrm{y}} \mathrm{F}_{2 \mathrm{x}} \mathrm{F}_{2 \mathrm{y}} \mathrm{F}_{3 \mathrm{x}} \mathrm{F}_{3 \mathrm{y}}$ & 8 & 4 \\
\hline 10 & $\mathrm{G}_{1 \mathrm{a}} \mathrm{G}_{1 \mathrm{~b}} \mathrm{~F}_{1 \mathrm{a}} \mathrm{F}_{1 \mathrm{~b}} \mathrm{~F}_{1 \mathrm{c}} \mathrm{F}_{2 \mathrm{a}} \mathrm{F}_{2 \mathrm{~b}} \mathrm{~F}_{2 \mathrm{c}} \mathrm{F}_{3 \mathrm{x}} \mathrm{F}_{3 \mathrm{y}}$ & 10 & 4 \\
\hline 11 & $\mathrm{G}_{1 \mathrm{a}} \mathrm{G}_{1 \mathrm{~b}} \mathrm{~F}_{1 \mathrm{a}} \mathrm{F}_{1 \mathrm{~b}} \mathrm{~F}_{1 \mathrm{c}} \mathrm{F}_{2 \mathrm{a}} \mathrm{F}_{2 \mathrm{~b}} \mathrm{~F}_{2 \mathrm{c}} \mathrm{F}_{3 \mathrm{a}} \mathrm{F}_{3 \mathrm{~b}} \mathrm{~F}_{3 \mathrm{c}}$ & 11 & 4 \\
\hline 12 & $\mathrm{G}_{1 \mathrm{a}} \mathrm{G}_{1 \mathrm{~b}} \mathrm{G}_{1 \mathrm{c}} \mathrm{F}_{1 \mathrm{a}} \mathrm{F}_{1 \mathrm{~b}} \mathrm{~F}_{1 \mathrm{c}} \mathrm{F}_{2 \mathrm{a}} \mathrm{F}_{2 \mathrm{~b}} \mathrm{~F}_{2 \mathrm{c}} \mathrm{F}_{3 \mathrm{a}} \mathrm{F}_{3 \mathrm{~b}} \mathrm{~F}_{3 \mathrm{c}} \mathrm{F}_{4 \mathrm{a}, \mathrm{b}} \mathrm{F}_{5 \mathrm{a}, \mathrm{b}}$ & 16 & 6 \\
\hline
\end{tabular}

Note: Where specific species identity is not shown (i.e., where there is an " $\mathrm{x}$ " or " $\mathrm{y}$ " subscript denoting species identity), for each replicate of that treatment, the species was drawn at random from the pool of three species comprising that functional group. 
Table 2: Native species, functional type, and code used in experimental assemblages

\begin{tabular}{lll}
\hline Species & \multicolumn{1}{c}{ Functional group } & Species code \\
\hline Festuca idahoensis & Grasses & $\mathrm{G}_{1 \mathrm{a}}$ \\
Koelaria macrantha & Grasses & $\mathrm{G}_{1 \mathrm{~b}}$ \\
Poa sandbergii & Grasses & $\mathrm{G}_{1 \mathrm{c}}$ \\
Geum triflorum & Early season, rhizomatous & $\mathrm{F}_{1 \mathrm{a}}$ \\
Antennaria rosea & Early season, rhizomatous & $\mathrm{F}_{1 \mathrm{~b}}$ \\
Penstemon procerus & Early season, rhizomatous & $\mathrm{F}_{1 \mathrm{c}}$ \\
Arnica sororia & Midseason, spreading rhizomes & $\mathrm{F}_{2 \mathrm{a}}$ \\
Achillea millefolium & Midseason, spreading rhizomes & $\mathrm{F}_{2 \mathrm{~b}}$ \\
Monarda fistulosa & Midseason, spreading rhizomes & $\mathrm{F}_{2 \mathrm{c}}$ \\
Penstemon wilcoxii & Midseason, woody root crowns & $\mathrm{F}_{3 \mathrm{a}}$ \\
Potentilla arguta & Midseason, woody root crowns & $\mathrm{F}_{3 \mathrm{~b}}$ \\
Gaillardia aristata & Midseason, woody root crowns & $\mathrm{F}_{3 \mathrm{c}}$ \\
Dodecatheon pulchellum & Spring ephemerals, shallow taproot & $\mathrm{F}_{4 \mathrm{a}}$ \\
Lewisia rediviva & Spring ephemerals, shallow taproot & $\mathrm{F}_{4 \mathrm{~b}}$ \\
Aster falcatus & Late season, deep taproot & $\mathrm{F}_{5 \mathrm{a}}$ \\
Artemesia frigida & Late season, deep taproot & $\mathrm{F}_{5 \mathrm{~b}}$ \\
\hline
\end{tabular}

plots in a fallow field at Fort Missoula, Missoula County, Montana. We watered and tilled the field and treated it with the herbicide Roundup (to reduce agricultural weeds) before planting. We established $723 \times 3$-m mixed-species plots (12 diversity treatments $\times 2$ water treatments $\times 3$ replicates $=72$ ), with each plot divided into four spatially separate $1.3 \times 1.3-\mathrm{m}$ subplots (separated by $0.2-\mathrm{m}$ buffer strips; fig. 1). Subplots within plots were planted with identical mixes of native species at identical initial densities. In spring 2004, we established six additional $3 \times 3$-m plots (three watered, three unwatered), with each plot containing three subplots planted with monocultures of the three exotics. As for natives, exotics were first grown in a greenhouse and then transplanted into a subplot within each $3 \times 3-\mathrm{m}$ plot.

Plots were arranged in three blocks separated by $6 \mathrm{~m}$; plots within blocks were separated by $3 \mathrm{~m}$. Natives were planted at an initial density of 32 individuals per subplot and supplemented in April 2004 with an additional 16 individuals per subplot. Exotic monocultures were planted at 48 individuals per subplot. The ultimate density of species in subplots, however, was considerably higher than planted density due to natural recruitment following abundant set seed in 2004-2006. Assemblages were weeded continuously to maintain predetermined levels of species and functional richness. Continuous weeding enabled us to remove plants when tiny, thereby minimizing disturbance.

Three months before the first invading assemblages, in May 2004, we initiated the water addition treatment, which we maintained through 2007 . We supplemented water because soil moisture limits plant production in arid grasslands in the intermountain West (Sheley et al. 1999). We added supplemental water to plots weekly during May and June. We watered when it was not raining and it had been dry for at least $24 \mathrm{~h}$. We watered during relatively wet months (May and June) because we wanted to enhance the range of natural variability in rainfall, as opposed to watering in summer, when it is normally dry. Plots were watered via a $1.25-\mathrm{cm}$-diameter soaker hose that was installed in a zigzag pattern across each plot. We added 5 $\mathrm{cm}$, or twice the long-term monthly average rainfall, in each of these months. During weeks of heavy rainfall in May/June, we covered control plots with $4.5 \times 4.5-\mathrm{m}$ clear plastic tarps ( $80 \%$ light transmittance) to preserve treatment differences. Plots were covered on four occasions in 2005, once in 2006, and twice in 2007, usually for less than $24 \mathrm{~h}$.

We invaded assemblages with exotics that differed in functional attributes. For example, dalmatian toadflax (hereafter toadflax) blooms in midseason and has a woody root crown but also produces vegetative horizontal or lateral roots that produce adventitious buds $\left(\mathrm{F}_{2}\right.$; table 2$)$. In contrast, sulfur cinquefoil (hereafter cinquefoil) also blooms in midseason but has a single large woody root crown or taproot. It is very similar in morphology and phenology to Potentilla arguta, the native cinquefoil, and is functionally similar to natives in forb functional group $3\left(\mathrm{~F}_{3}\right.$; table 2$)$. Finally, spotted knapweed (hereafter knapweed) is a deeply taprooted species that is extremely late blooming. In September 2004, after natives had established for two growing seasons, we randomly selected and invaded three of the four subplots within each plot with an equal number of seeds of a unique exotic. We added $10.71 \mathrm{~g}$ of knapweed seeds, $0.76 \mathrm{~g}$ of toadflax seeds, or $0.85 \mathrm{~g}$ of cinquefoil seeds to a randomly selected subplot within each plot. In September 2005, half the number of seeds added in 2004 were again added to the same subplots. We placed seeds in the central $1 \mathrm{~m}^{2}$ of each subplot, and for each invader, total seed weight 


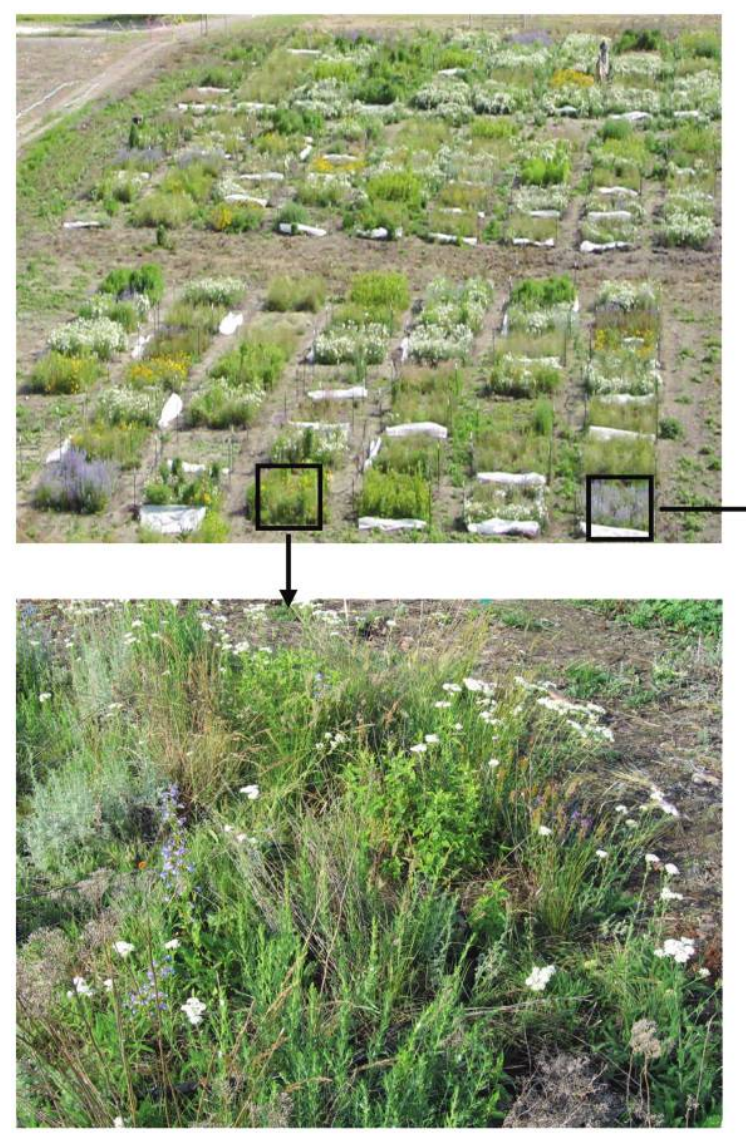

$1.3 \mathrm{~m}$

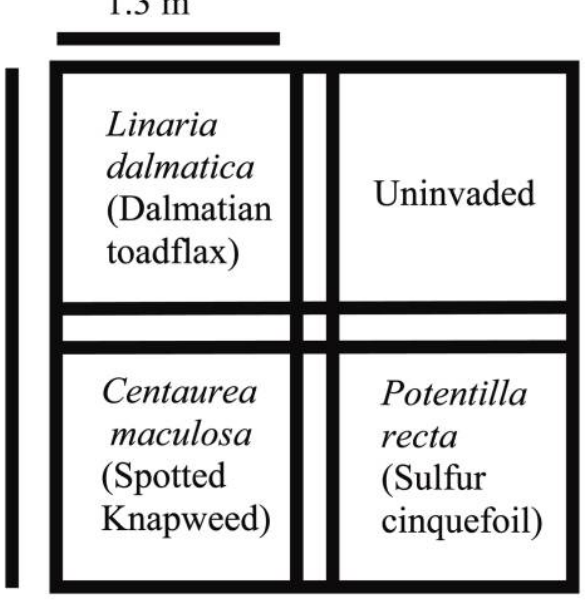

Figure 1: Top left, Experimental plots. The cluster of plots at bottom of photo represents one experimental block; bottom left, one experimental plot in summer 2006; right, schematic of plot layout. Identity of invader (or uninvaded control) was assigned randomly to each subplot.

added across both years corresponded to 7,500 seeds. Exotic seeds were collected locally.

\section{Data Collection}

To ensure that effects of diversity on invasibility were not due to reduced cover in more diverse assemblages, in April 2005, the first spring after invasion, we estimated percent cover of all native plants and bare ground within a $1-\mathrm{m}^{2}$ quadrat placed in the center of all invaded assemblages. In September 2006, we counted the number of flowering stems of each exotic within the central $1 \mathrm{~m}^{2}$ of each invaded subplot. From late June through mid-July 2007, at peak biomass production, we (1) counted the number of flowering stems of each exotic that were rooted within a $0.75 \times 0.75-\mathrm{m}$ quadrat placed in the center of each mixedspecies and exotic monoculture subplot and (2) harvested all aboveground biomass rooted in each quadrat. We harvested unwatered assemblages first, because plants were at their peak biomass sooner than plants in watered assem- blages. One of the spring ephemerals in the 16-species mixes, Dodecatheon pulchellum, had senesced before our harvest, so biomass of this species is missing. However, these are extremely small-statured plants that occurred at low density, and thus, their cumulative biomass per subplot was probably very small. Plants were cut at ground level, sorted by species, and bagged individually. Flowering and nonflowering exotics were also bagged separately. Harvested plants were dried to a constant weight and then weighed.

We calculated total exotic biomass in each invaded subplot and total native biomass in each uninvaded and invaded subplot. Invader impact was assessed as in other studies (Dukes 2002), by calculating the difference in total native biomass (both on an absolute and a percentage basis) between uninvaded and invaded subplots within the same plot. If native biomass was greater in invaded than uninvaded subplots, or if there were no exotics in a particular invaded subplot, then impact was designated as zero. 
Since early in the experiment it was clear that knapweed had greater success in invading assemblages than the other two exotics, we examined knapweed impact in more detail. We quantified knapweed impact on plant-available soil nitrogen by comparing the amount of $\mathrm{NO}_{3}^{-}$and $\mathrm{NH}_{4}^{+}$ sorbed to ion-exchange resin capsules (containing $1 \mathrm{~g}$ of ionic resin; Unibest, Bozeman, MT) through the growing season in uninvaded and knapweed-invaded subplots. In late April 2006, we buried two resin capsules at a depth of $10 \mathrm{~cm}$ in haphazardly selected locations in the center of each uninvaded and knapweed-invaded subplot. At the end of the growing season, in mid-July 2006, we excavated these resin capsules, placed them in a cooler with ice, and transported them to the laboratory. We subsequently extracted $\mathrm{NO}_{3}^{-}$and $\mathrm{NH}_{4}^{+}$by bathing each capsule in three sequential 1 -h rinses of $2 \mathrm{M} \mathrm{KCl}$ (10 $\mathrm{mL}$ per rinse). Capsules were gently shaken on a shaker table during each rinse, after which KCL extracts were decanted to create a total extract volume of $30 \mathrm{~mL}$. Extracts were then analyzed for $\mathrm{NH}_{4}^{+}$and $\mathrm{NO}_{3}^{-}$on an Autoanalyzer III (Bran Luebbe, Chicago). We calculated the mean nitrogen values from the two resin capsules buried in each subplot and used these values in analyses.

We measured soil moisture in uninvaded and knapweedinvaded subplots during the peak of the growing season, on June 13, June 23, July 3, and July 12, 2006. We inserted a TRIME FM TDR probe (Mesa Systems, Medfield, MA) in 5.1-cm-diameter PVC access pipes that were installed in the centers of subplots in summer 2003 or 2004 to obtain measures of soil moisture at 5-15- and 35-50-cm depths.

To determine how knapweed impacts on soil nitrogen and moisture levels might have been affected by knapweed biomass, we converted counts of the number of knapweed flowering stems made in September 2006 to biomass. We used regressions relating number of flowering stems to aboveground biomass from 2007 (unwatered assemblages: $R^{2}=0.67, F=69.3, \mathrm{df}=1,34, P<.0001$; watered assemblages: $R^{2}=0.45, F=37.7$, df $=1,34, P<.0001$ ), to estimate knapweed biomass in 2006.

\section{Statistical Methods}

Although we varied both species and functional richness, these two variables were strongly correlated across assemblages (Pearson $r=0.88$ ), making simultaneous analyses of both factors difficult. Accordingly, we ran separate models using either species or functional richness as a covariate. These models produced $R^{2}$ values that were within $1 \%-$ $2 \%$ of each other, and in almost all cases, models using species richness accounted for slightly more variation than models using functional richness. Thus, we focus here on examining the effects of species richness.
Throughout the experiment, particularly in 2006 and 2007, native species richness in some of the more diverse assemblages declined from their original levels at planting. For example, at the end of the experiment, 16- and 11species mixes had lost, on average, 3.5 species each ( \pm SEM 0.33 and 0.36 for 16 and 11 species, respectively). Against this change, invasion occurred cumulatively across years (2004-2007, from experimental seed additions in 2004 and 2005 and from natural seed rain in 2005 and 2006). Because invasion in higher-diversity mixes (where there was greater species loss than in less diverse mixes) did not accelerate through time (i.e., population growth across years was actually highest in low-diversity assemblages; J. Maron and M. Marler, unpublished data), and because results did not change if we instead used the species richness in subplots at the end of the experiment, we used the planted species richness in all analyses.

We took a hierarchical approach to data analysis. We used split-plot ANCOVA (within the PROC MIXED module of SAS, ver. 9.1) to determine how block, water treatment, invader identity, and native species richness influenced (1) exotic plant biomass (i.e., invasibility), (2) the absolute and percent (arcsine-square root transformed) reduction in native plant biomass caused by exotics (i.e., invader impact), and (3) total plant available nitrogen $\left(\mathrm{NO}_{3}^{-}+\mathrm{NH}_{4}^{+}\right.$, square root transformed) between uninvaded and knapweed-invaded subplots. Water treatment and invader identity were fixed factors, block was a random factor, and plots were considered split among invader types, with water being applied at the whole-plot level. Species richness was used as a continuous covariate. For the test examining the effects of knapweed invasion on nutrients, the factor "invader identity" refers to either knapweed-invaded or uninvaded subplots.

We also determined how per capita impacts of invaders differed. We did this by using exotic biomass as a second covariate in the analysis described above, where invader impact was the response variable. By using exotic biomass as a second covariate, we could "control" for variation in exotic biomass and then determine how impacts differed among invaders, by water treatment, and by species richness. An alternative approach would have been to calculate per capita impact (impact divided by exotic biomass) and use this as a response variable (thereby eliminating the need to use exotic biomass as a covariate). We could not use this approach, however, since this resulted in highly skewed values with heterogeneous variances that could not be normalized via transformation.

We initially tested models that included all two-way interactions (water treatment $x$ diversity, invader identity $\times$ diversity, and invader identity $\times$ water treatment) plus the three-way interaction (water treatment $\times$ diversity $x$ invader). This three-way interaction, however, 
was never significant, so we proceeded to test models with only two-way interactions. If two-way interaction terms involving the covariate species richness were not significant, they were also dropped from the final model. If the invader identity $\times$ species richness interaction was significant, it indicated that the slope of the diversity-invasibility or diversity-impact relationship varied among the three exotics. If that was the case, we proceeded to test each invader separately, using two-way ANCOVAs with water treatment as a fixed factor and species richness as a covariate. In these individual models, the diversity $\times$ water treatment interaction was never significant, so we report the effects of species richness and water treatment after this interaction term was dropped. Tests for effects of species richness involve 12 diversity treatments $\times 3$ replicates $\times 3$ exotic species (subplots within a split plot) $\times 2$ water treatments $=216$.

We used split-plot ANCOVA (as above) to determine how the percent native plant cover (arcsine-square root transformed) in invaded assemblages varied as a function of species richness and water treatment in April 2005, during the first spring of invasion. We used a two-way ANOVA to compare the biomass of natives in univaded 16-species mixes with the biomass of exotics in monoculture. The model had water treatment, plant identity (native vs. cinquefoil, knapweed, or toadflax), and their interaction as fixed factors. We used paired $t$-tests to compare the biomass in uninvaded subplots with the biomass in invaded subplots within the same plot.

To examine impacts of water addition and knapweed invasion on soil moisture, we performed repeated-measures (rm)ANCOVA using measures of soil moisture taken at four times in the middle of the growing season in 2006. In this model, species richness was a covariate, and water treatment and invasion (knapweed-invaded or not) were fixed factors.

\section{Results}

\section{Invasibility}

In a full ANCOVA model with all two-way interactions, exotic biomass declined strongly with increasing species richness (fig. 2; $F=38.7$, df $=1,202, P<.0001$ ) despite the fact that native cover in invaded subplots (when invasion began in spring 2005) did not vary with species richness $(F=1.5$, df $=1,207, P=.22)$. Although the effect of resource (water) supply on invasibility was not statistically significant $(F=0.01$, df $=1,43.4, P=.95)$, there was a significant water treatment $\times$ invader identity interaction $(F=4.2, \mathrm{df}=2,202, P<.02)$, indicating that the influence of water addition on invasibility varied by the species of exotic. For individual exotics, water ad- dition significantly increased knapweed invasion (fig. 2; $F=5.67, \mathrm{df}=1,67, P<.03)$ but not invasion by cinquefoil (fig. $2 ; F=1.1$, df $=1,68, P=.29$ ) or toadflax (fig. $2 ; F=0.01, \mathrm{df}=1,69, P=.98)$. Across both water treatments, the three exotics also differed in their ability to invade assemblages (ANCOVA, $F=71.9$, $\mathrm{df}=2,202$, $P<.0001)$. Because the species richness $\times$ invader interaction was significant, we could not evaluate the relative invasiveness of the three exotics in post hoc comparisons. But in a simple comparison of weed biomass across all assemblages, mean knapweed biomass across all dry mixed-species assemblages was $674 \mathrm{~g} / 0.56 \mathrm{~m}^{2}$ compared with $158 \mathrm{~g} / 0.56 \mathrm{~m}^{2}$ for toadflax and $64 \mathrm{~g} / 0.56 \mathrm{~m}^{2}$ for cinquefoil, a significant difference (Tukey post hoc test, $P<.0001)$. Toadflax and cinquefoil biomass were not significantly different from one another (Tukey post hoc test, $P=.51)$. In watered assemblages, the mean biomass of the three exotics was 941,160 , and $82 \mathrm{~g} / 0.56 \mathrm{~m}^{2}$ for knapweed, toadflax, and cinquefoil, respectively. Again, knapweed biomass was significantly greater than that of the other two exotics (Tukey post hoc test, $P<.0001$ ), but toadflax and cinquefoil biomass did not differ significantly (Tukey post hoc test, $P=.62$ ).

Although elevating resource supply increased the total biomass of knapweed in assemblages, it did not change the slope of the diversity-invasibility relationship (fig. 2; species richness $\times$ water treatment interaction: $F=0.12$, $\mathrm{df}=1,66, P=.73)$. The relationship, however, did vary among the three exotics (species richness $\times$ invader interaction: $F=16.96, \mathrm{df}=2,202, P<.0001)$. In separate tests for each exotic, the effects of species richness on invasibility was significant (cinquefoil: $F=4.8, \mathrm{df}=$ 1,69, $P<.05$; knapweed: $F=29.3$, df $=1,67, P<.0001$; toadflax: $F=5.0, \mathrm{df}=1,69, P<.05)$. Thus, although diversity had substantial negative effects on invasion, the strength of these effects varied among the exotics.

\section{Invader Impact on Native Biomass}

As was the case for invasibility, species richness had strong negative effects on invader impact (fig. 2). Both the difference in native biomass $(F=14.1, \mathrm{df}=1,205, P<$ $.001)$ and the percentage difference in native biomass declined with increasing species richness (fig. 2; $F=17.9$, $\mathrm{df}=1,205, P<.0001)$. When impact values were allowed to be negative (instead of all negative values being set to $0)$, there was still a significant effect of species richness on impact $(F=11.3, \mathrm{df}=1,205, P<.001)$. The magnitude of invader impact on native plant biomass (the percent difference between uninvaded and invaded subplots) differed among the three exotics $(F=22.0$, df $=2,205$, $P<.0001)$. Knapweed invasion produced, on average, a $52.7 \%$ reduction in native biomass. This was significantly 
INVASIBILITY
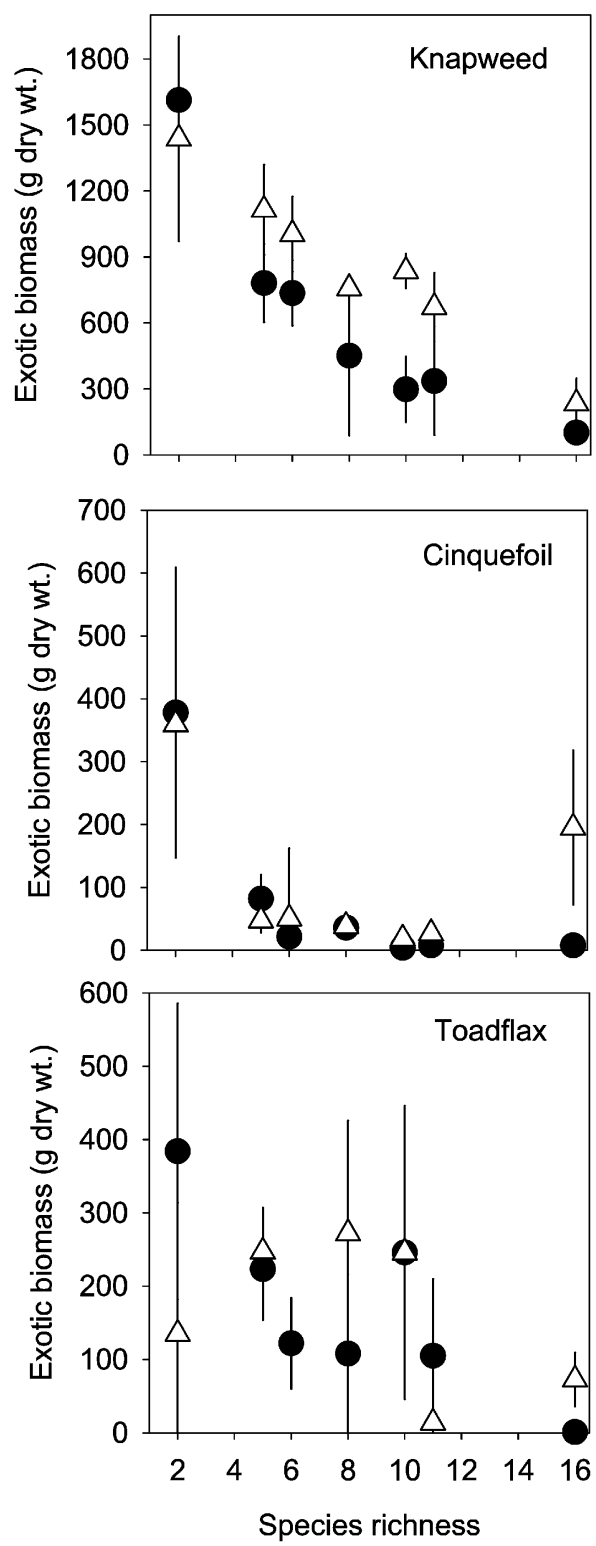

\section{INVADER IMPACT}
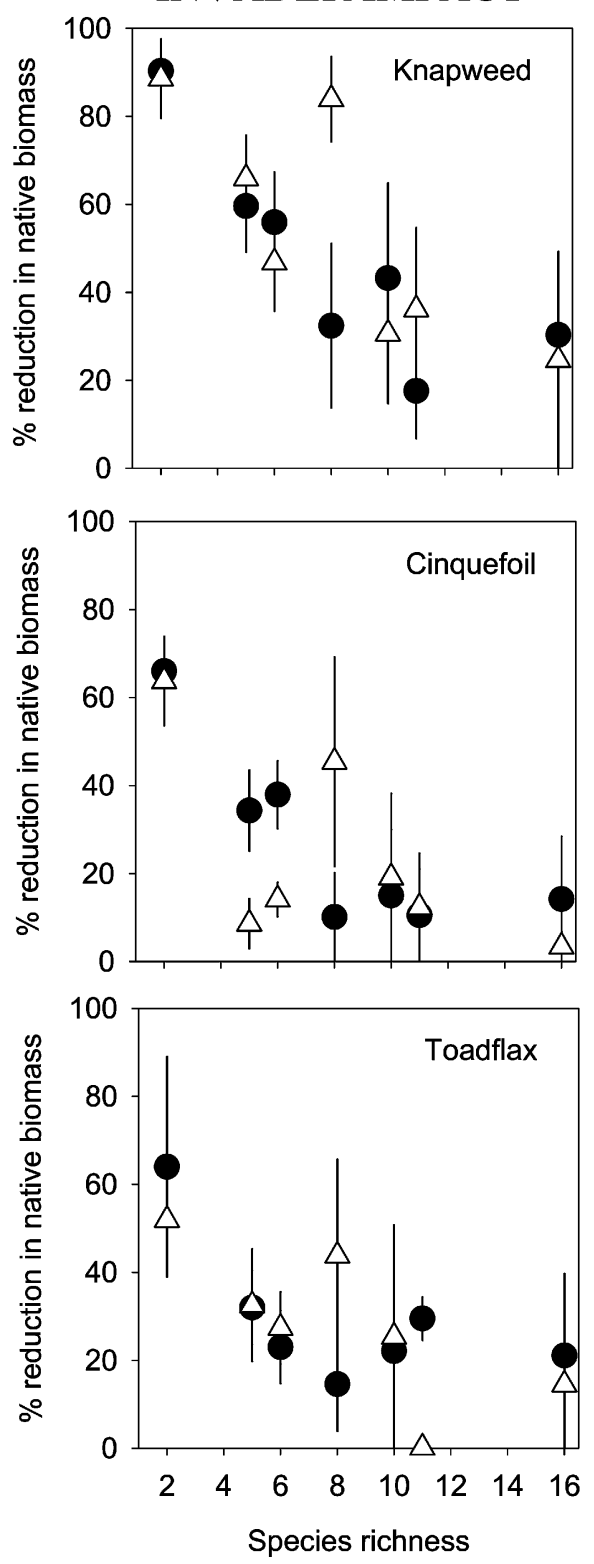

Figure 2: Effect of native species richness on invasibility (left column), quantified as mean ( \pm SE) aboveground biomass of exotics in each assemblage, and invader impact (right column), quantified as mean ( $\pm \mathrm{SE}$ ) percent reduction in the aboveground biomass of native plants in uninvaded versus invaded subplots in the same plot. If native biomass was higher in invaded versus uninvaded plots, impact was assigned zero. Circles $=$ dry assemblages, triangles $=$ wet assemblages.

greater than the decline in native biomass caused by toadflax (mean decline in native biomass $=25.2 \%$ ) or cinquefoil (mean decline in native biomass $=22.1 \%$; Tukey post hoc comparison, $P<.0001$ ). Toadflax and cinquefoil impacts on natives were not significantly different from each other (Tukey post hoc comparison, $P=.83$ ).

Unlike having a weak effect on invasibility, increased water supply had no effect on invader impact (fig. 2; $F=0.07$, df $=1,4, P=.80)$. There was no significant water treatment $\times$ invader identity interaction $(F=1.3$, $\mathrm{df}=2,205, \quad P=.27)$ or species richness $\times$ invader identity interaction $(F=0.75$, df $=2,202, P=.47)$ on invader impact.

The impact of invaders roughly scaled with invader bio- 

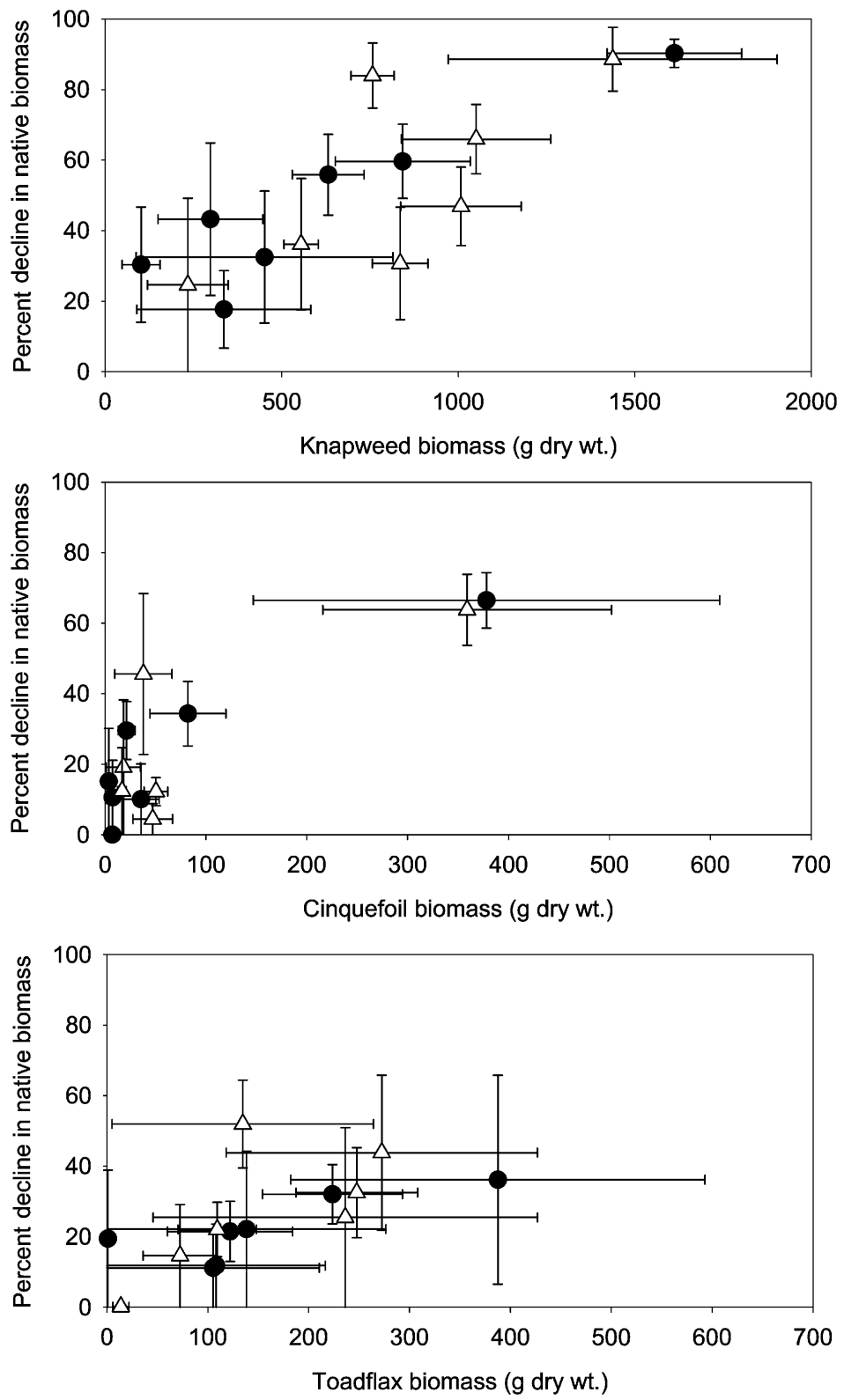

Figure 3: Relationship between mean $( \pm$ SE) aboveground biomass of exotics in invaded assemblages and mean $( \pm$ SE) percent difference in aboveground biomass of natives between uninvaded and invaded subplots in the same plot. Means calculated for assemblages with identical background species richness $(2,5,6,8,10,11$, or 16 species). Calculation of invader impact described in "Methods." Circles $=$ dry assemblages, triangles $=$ wet assemblages. For knapweed, $R^{2}=0.66, F=23.6, \mathrm{df}=1,12, P<.0001$; for cinquefoil, $R^{2}=0.53, F=13.7, \mathrm{df}=1,12, P<.01$; for toadflax, $\left.R^{2}=0.42, F=8.6, \mathrm{df}=1,12, P<.01\right)$.

mass and, thus, invasibility. In analyses to explore per capita (g biomass) impacts of exotics, exotic biomass strongly affected impact (ANCOVA, $F=48.8, \mathrm{df}=$ $2,207, P<.0001)$. Mean invader impact across the diversity gradient was a function of mean exotic abundance across this gradient (fig. 3). After statistically controlling for variation in invasibility (i.e., exotic biomass), there were no differences among exotics in impacts $(F=1.1$, $\mathrm{df}=2,205, P=.33)$ nor were impacts different between water treatments $(F=0.33, \mathrm{df}=1,4, P=.59)$. The effect of species richness on invader per capita impact, however, was still significant $(F=5.4, \mathrm{df}=1,204, P<.03)$.

We also found significant negative relationships between exotic biomass and native biomass in invaded subplots 

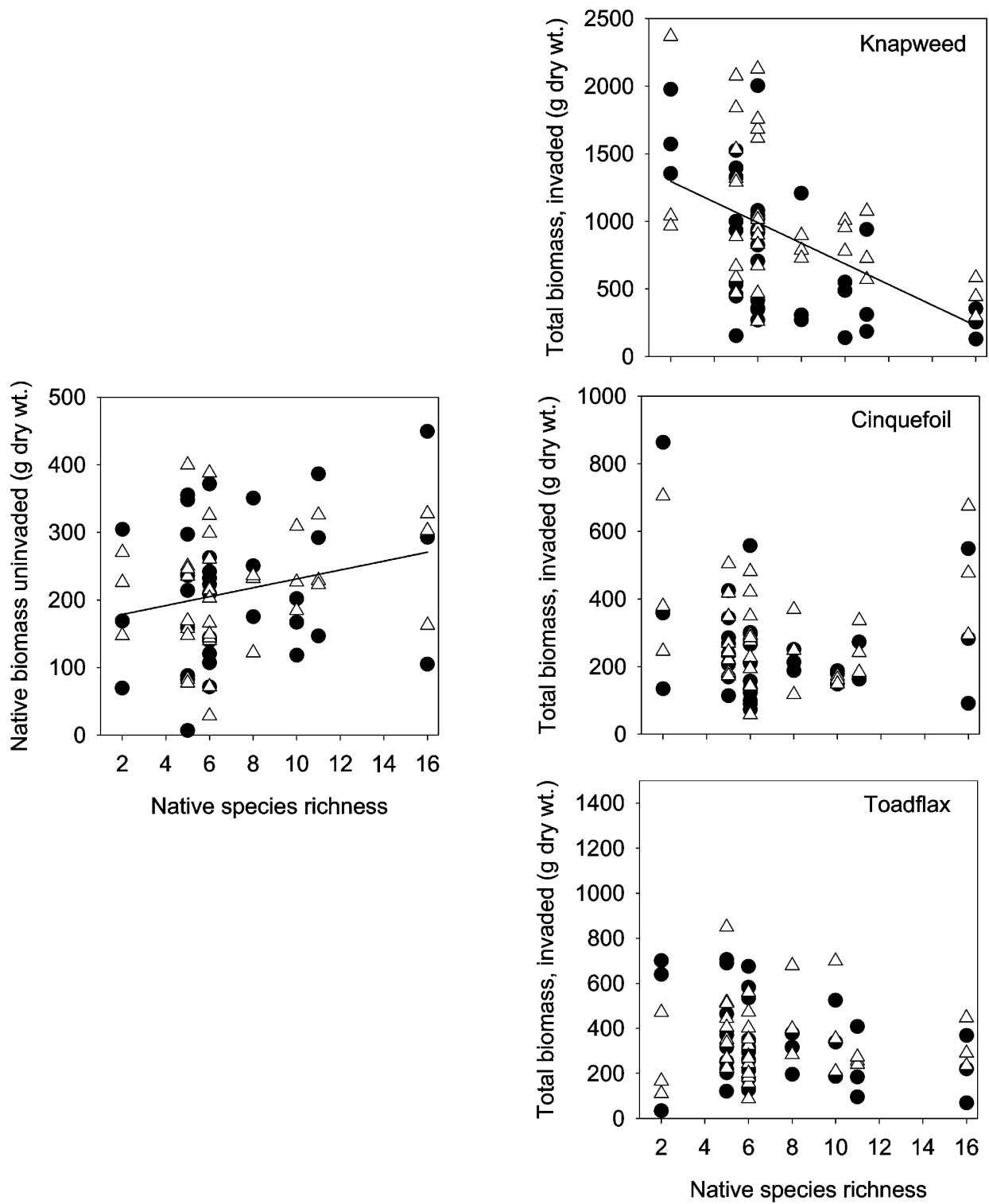

Figure 4: Relationship between native species richness and native plant biomass in uninvaded assemblages (left) and native plus exotic plant biomass in invaded assemblages $($ right $)$. Circles $=$ dry assemblages, triangles $=$ wet assemblages.

(cinquefoil: $R^{2}=0.07, \quad F=5.0, \quad \mathrm{df}=1,70, \quad P<.03$; knapweed: $R^{2}=0.38, F=42.4$, df $=1,70, P<.0001$; toadflax: $\left.R^{2}=0.20, F=17.9, \mathrm{df}=1,70, P<.0001\right)$. In uninvaded assemblages, overall productivity increased with increasing diversity (fig. $4 ; F=4.3$, df $=1,69$, $P=.043)$. Knapweed invasion, however, switched the slope of the diversity-yield relationship from positive (in uninvaded plots) to negative (in invaded plots where yield was native and invader biomass combined; fig. 4; ANCOVA, $F=26.6, \mathrm{df}=1,69, P<.0001)$. For cinquefoil and toadflax, there was no significant relationship be- tween native species richness and the total productivity of invaded assemblages $(F=0.31, \mathrm{df}=1,69, P=.86$ and $F=1.8, \mathrm{df}=1,69, P=.19$ for cinquefoil- and toadflaxinvaded subplots, respectively). Although invasion generally resulted in a decrease in native biomass, the overall effect was often to increase total plant biomass (fig. $5 \mathrm{~A}$ ). The total biomass of each invaded assemblage was greater than the biomass of the paired uninvaded assemblage (paired $t$-test; cinquefoil: $t=-2.8, \mathrm{df}=71, P<.008$; knapweed: $t=-10.5, \mathrm{df}=71, P<.0001$; toadflax: $t=$ $-5.44, \mathrm{df}=71, P<.0001)$. Ninety-six percent of knap- 

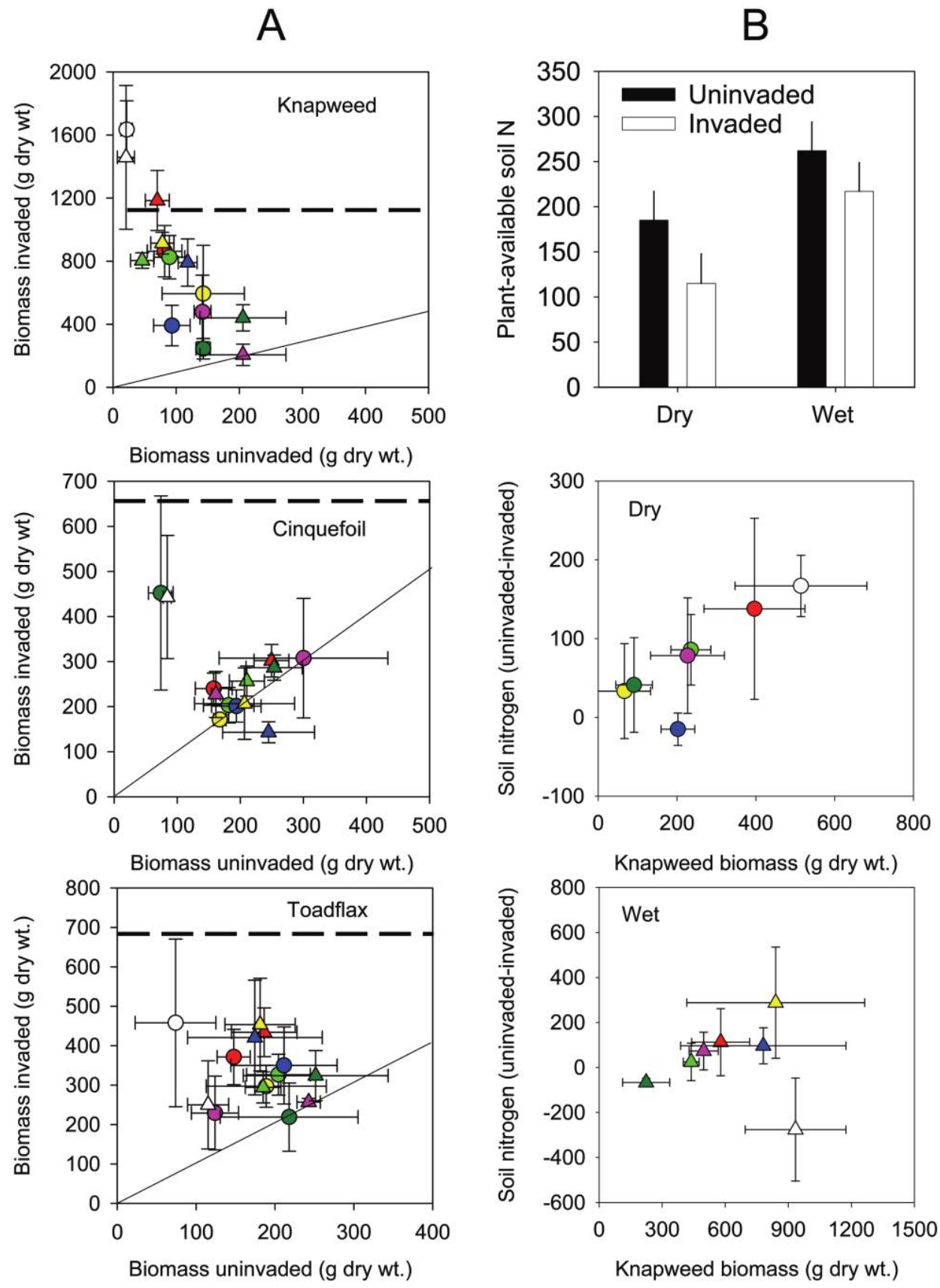

Figure 5: $A$, Relationship between mean $( \pm \mathrm{SE})$ aboveground biomass (natives plus exotics) in invaded assemblages and mean $( \pm \mathrm{SE})$ aboveground biomass of natives in univaded assemblages. Circles $=$ dry assemblages, triangles $=$ wet assemblages. Diagonal represents the $1: 1$ line, where native biomass in uninvaded subplots equals the biomass of natives plus exotics in invaded subplots within the same plot. Dashed line is the mean biomass of each exotic grown in monoculture. Points above this line indicate that invaded assemblage productivity overyielded compared with the exotic in monoculture. $B(t o p)$, Effect of knapweed invasion on least squared mean $(+\mathrm{SE})$ plant-available nitrogen $\left(\mathrm{NH}_{4}^{+}+\mathrm{NO}_{3}^{-}\right)$sorbed to resin capsules throughout growing season in dry and watered assemblages. Least squared means calculated in model using species richness as a covariate. $B$ (middle, bottom), Effect of mean ( \pm SE) knapweed biomass (in 2006) on mean $( \pm S E)$ difference in plant-available soil nitrogen between uninvaded and invaded subplots that were either dry (middle) or wet (bottom). For dry assemblages, $R^{2}=0.71, F=12.2, \mathrm{df}=1,5, P=.018$; for wet assemblages, $R^{2}=0.0001, F=0.004, P=.98$. Knapweed biomass in 2006 estimated based on counts of flowering stems per subplot in 2006 and the relationship between flowering stems and biomass in 2007. For all colored graphs, means were calculated for assemblages with identical background species richness (2 [white], 5 [red], 6 [light green], 8 [yellow], 10 [blue], 11 [pink], or 16 [dark green] species). 
weed-invaded assemblages had higher biomass than their uninvaded controls (fig. $5 \mathrm{~A}$ ). For toadflax, $71 \%$ of invaded assemblages had higher biomass than controls, whereas $60 \%$ of cinquefoil-invaded assemblages had higher biomass than their uninvaded controls (fig. 5A). Exotic monocultures tended to have greater productivity than even the most diverse uninvaded assemblages, although these differences were not statistically significant $(F=2.5, \mathrm{df}=$ $3,16, P=.095)$. Water addition had no significant effect on exotic biomass in monoculture or on total native biomass in 16 species mixes (effects of water: $F=0.90$, $\mathrm{df}=1,16, P=.36$; interaction between water and plant identity: $F=0.65$, df $=3,16, P=.60$ ).

\section{Invader Impact on Soil Nitrogen and Moisture}

Knapweed not only depressed native plant biomass but also resulted in changes in resource availability. Knapweed invasion reduced plant-available nitrogen (fig. $5 B$; ANCOVA, $F=4.04, \mathrm{df}=1,136, P<.05)$ and decreased shallow soil moisture (rmANCOVA, $F=7.6, \mathrm{df}=$ $1,131, P<.01$ ) but not deep soil moisture (rmANCOVA, $F=0.077, \mathrm{df}=1,131, P=.78)$. Water addition increased plant-available nitrogen (ANCOVA, $F=10.9$, $\mathrm{df}=1,136, P<.01)$ and shallow but not deeper soil moisture (rmANCOVA: shallow, $F=19.7$, df $=1,131, P<$ .0001 ; deep, $F=0.24$, $\mathrm{df}=1,131, P=.62)$. Soil nitrogen $(F=0.43, \mathrm{df}=1,136, P=.51)$ and soil moisture (shallow: $F=0.25, \mathrm{df}=1,131, P=.62$; deep: $F=0.22$, $\mathrm{df}=1,131, P=.64)$ did not vary significantly across the diversity gradient, although there was a marginally significant species richness $x$ invasion interaction for shallow soil moisture (rmANCOVA, $F=3.5, \mathrm{df}=1,131$, $P=.06$ ), suggesting that the effects of species richness on soil moisture were different between control and knapweed-invaded plots. However, when tests were run for knapweed-invaded and control subplots separately, the effects of species richness on shallow soil moisture were not significant (control plots: $P=.10$; watered plots: $P=$ .33). For both soil nitrogen and soil moisture, there were no significant water addition $\times$ species richness interactions (soil nitrogen, $P=.88$; shallow soil moisture, $P=.21$; deep soil moisture, $P=.41$ ). For both dry and wet assemblages, there was no significant relationship between mean knapweed biomass and mean impact on soil moisture for any date $(P>.05)$. In contrast, the impacts of knapweed on soil nitrogen scaled directly to its mean biomass in dry (but not wet) assemblages (fig. $5 B$ ). Finally, mean knapweed impacts on soil nitrogen in 2006 did not correlate with mean impacts on native plant biomass in 2007 (Pearson $r=0.04, P=.73$ ).

\section{Discussion}

Our experiment yielded four main results. First, high native plant diversity substantially inhibited exotic invasion, and in doing so, it reduced the impact of invaders on the native community. Although negative effects of diversity on invasibility have been shown in other studies (Levine 2000; Naeem et al. 2000; Prieur-Richard et al. 2000; Symstad 2000; Dukes 2002; Kennedy et al. 2002; Fargione et al. 2003; van Ruijven et al. 2003; Zavaleta and Hulvey 2004; Maron and Marler 2007), few studies have examined how diversity influences invader impact, aside from those of Dukes (2002) and Zavaleta and Hulvey (2004). Dukes (2002) found weak effects of diversity on invader impact. Zavaleta and Hulvey (2004), using the same invader as Dukes (2002), found that the per capita effects of Centaurea soltitialis on total resident biomass actually increased with increasing diversity. We found consistently strong negative effects of diversity on both invasibility and impact. These effects occurred despite the fact that we (1) excluded monocultures from the analyses, which are usually highly invaded (and presumably impacted) and therefore can inflate estimates of effects of diversity on invasibility/impact (Wardle 2001), and (2) invaded native assemblages with very potent invaders ("strong invaders" sensu Ortega and Pearson 2005)—exotics that occur at very high density in grasslands in the intermountain West of the United States. Interestingly, however, the slope of the diversity-invasibility/impact relationship differed among the three exotics we used, suggesting that there are inherent differences even among strong invaders in how they respond to native diversity and resource supply.

The second major finding was that the impacts of exotics on native biomass scaled directly as a function of exotic biomass. In other words, exotics had their greatest impacts in assemblages that were heavily invaded. This suggests that the same mechanisms that can control invasibility affect impact, a link that has been surprisingly missing in the invasion literature (Parker et al. 1999). Interestingly, however, when variation in exotic biomass was statistically "controlled," there was still a strong negative effect of diversity on impact. Although speculative at this juncture, it may be that greater resource preemption by natives in more diverse assemblages not only reduces invasion but also limits per capita impacts.

Third, contrary to Sperber et al. (2003), we found that knapweed had strong impacts on the abiotic environment (depressing soil moisture and nitrogen). Exotics are often thought to be successful because they preempt resources from natives (D'Antonio et al. 1998), but in our case, knapweed impacts on resource levels did not correlate with its impacts on native plant biomass. Finally, at least in the case of knapweed, resource supply had differential effects 
on invasibility and impact. Whereas water additions increased community susceptibility to knapweed invasion, the impact of knapweed on recipient assemblages was relatively unaffected by increased resource supply.

By itself, increased resource availability often renders communities more susceptible to invasion (Milchunas and Lauenroth 1995; Burke and Grime 1996; Maron and Connors 1996; Wedin and Tilman 1996; Davis and Pelsor 2001; Thomsen et al. 2006). By the same token, in isolation, experimentally increasing local diversity often reduces susceptibility to invasion because resource availability is more greatly depressed in higher versus lower diversity assemblages (Loreau and Hector 2001; Tilman et al. 2001; Kennedy et al. 2002; Fargione et al. 2003; Maron and Marler 2007). This begs the question: how strong are the direct effects of resource additions on facilitating invasion relative to the indirect effects of resource reductions (through effects of diversity) on resisting invasions? Gaining insight into how resource supply and changing diversity jointly influence invader impact is of growing importance, given that global climate change and anthropogenically caused atmospheric deposition of nitrogen are altering the availability of limiting resources (water and nitrogen) at the same time that native species diversity is declining ( Vitousek et al. 1997; Sheley et al. 1999; Houghton et al. 2001; Walther et al. 2002; Vilà et al. 2007). The only study of which we are aware that has examined the joint effect of resource additions and diversity on invasion found a strong interaction between these factors in rock pool microcosms (Romanuk and Kolasa 2005).

One could imagine a case where increasing resource supply would increase invader impact but not change the slope of a diversity-impact relationship, as we found for knapweed invasibility (this study; Maron and Marler 2007). Alternatively, if effects of resource supply were strong enough, the relationship between diversity and invasibility/impact could be erased. Indeed, Davis et al. (2000) proposed that community susceptibility to invasion is determined solely by changes in the availability of unused resources. Our results revealed that increased water supply increased both soil moisture (this study; Maron and Marler 2007; J. Maron and M. Marler, unpublished data) and soil nitrogen and decreased light availability (J. Maron and M. Marler, unpublished data). However, changing resource supply did not significantly affect how strongly invaders impacted native biomass. Knapweed was the only exotic that had significantly greater biomass in watered versus unwatered assemblages (although toadflax showed trends in this direction as well). Knapweed can sustain high transpiration without significantly lowering its water potential (Hill et al. 2006). We speculate that this may account for knapweed's substantial impacts on soil moisture, and high demand for water by knapweed might account for its greater success in watered versus unwatered assemblages. Yet, water additions increased not only exotic biomass but also native biomass. Thus, one likely explanation for the limited effects of resource supply on invader impact is that the benefits of water addition to natives equaled the benefits to exotics, making the net impact of exotics on natives no different between treatments. Another reason that increased resource supply may have had limited effects on invasibility and impact is that our watering treatment was very conservative. That is, we watered during spring, a time of year when rainfall is typical, and thus our treatment served to enhance soil moisture in a wet time of year.

The three exotic invaders varied substantially in their impacts on native biomass. Knapweed was clearly the most potent invader, and by dint of its greater biomass in invaded subplots, it had the greatest impacts compared to toadflax and cinquefoil. Why might these exotics differ so greatly in their invasion success? One possibility is that since we invaded assemblages with a greater weight of knapweed seeds than of the two other exotics (in order to keep seed number equal across species), this resulted in an initial bias in favor of knapweed. Although plausible, we think this explanation is unlikely. In seed addition experiments where we added an equal seed weight of the three exotics to small plots (thus lower numbers of knapweed seed compared with the other exotics), knapweed cover was still greater than the other two exotics 8 months after seed addition (J. Maron and M. Marler, unpublished data). These experiments, however, revealed a more likely explanation for the greater relative success of knapweed than toadflax or cinquefoil. Knapweed has substantial fall germination; there was, on average, 91\% cover of knapweed seedlings in plots just 2 months after September seed addition. In contrast, toadflax and cinquefoil had very limited fall germination, with an average of only $20 \%$ cover for toadflax and $7.6 \%$ cover for cinquefoil 2 months after September seed addition (J. Maron and M. Marler, unpublished data). This difference in fall germination likely has large effects on the ability of these species to invade native assemblages, since competition with natives at this time is minimal. In the same seed addition experiment described above, we added native seeds to their own separate plots. We used 11 of the native species that were part of the larger diversity-impact experiment. The average cover of seedlings in these plots 2 months after September seed addition was only $8.2 \%$ (J. Maron and M. Marler, unpublished data). As well, although some established natives will green up after fall rains, many established natives remain dormant through fall. Thus, there is limited competition between knapweed seedlings and established natives. In further support of this idea, we found that during the first 2 years of the diversity-invasibility experiment 
(where all knapweed recruitment was from added seed and thus propagule pressure was controlled), the magnitude of knapweed seedling recruitment in fall did not vary across the diversity gradient (Maron and Marler 2007). This further suggests that knapweed recruits in fall may experience very limited competition with existing natives. In addition to its unique "germination niche," unlike the other two exotics, knapweed is allelopathic (Callaway and Aschehoug 2000; Bais et al. 2003), which could also contribute to its invasion success.

Aside from differences in germination timing, other differences among the three exotics in the extent of their functional overlap with natives may account for variation in invasion success. For example, the one monoculture that had the greatest resistance to Potentilla recta invasion was that of the native cinquefoil, Potentilla arguta. However, the other two exotics invaded $P$. arguta monocultures as successfully as any other native monoculture (J. Maron and M. Marler, unpublished data). This suggests that at least for P. recta, the level of functional overlap with natives may play a role in limiting its invasion success. Others have also found that resident species are more resistant to invasion by exotics that are more similar to themselves than exotics less similar to themselves (Fargione et al. 2003; Fargione and Tilman 2005).

We previously showed that reduced resource availability in high-diversity assemblages contributes to increased resistance to knapweed invasion (Maron and Marler 2007). Consistent with more efficient or complete resource use in more diverse assemblages, we found that the productivity of uninvaded assemblages increased with increasing diversity. However, greater resource complementarity in high-diversity plots did not lead to transgressive overyielding (i.e., higher biomass in diverse mixtures than in the most productive monocultures of constituent species; J. Maron and M. Marler, unpublished data). Whatever combination of complementarity and other mechanisms may have influenced our results, the degree to which invasion increased total community productivity was striking. Knapweed invasion, in particular, actually switched the slope of the diversity-productivity relationship from positive in uninvaded assemblages to negative across invaded assemblages (fig. 4). Zavaleta and Hulvey (2004) similarly found that exotic yellow star thistle (C. soltitialis) increased total assemblage biomass more at low than at high levels of diversity.

Previous studies of biodiversity and ecosystem function have interpreted the greater production in more diverse plant assemblages (reviewed by Hooper et al. [2005]) as indicative of the "value" of biodiversity (Tilman et al. 1997; Naeem 2002), since plant productivity is one widespread metric of ecosystem function. For example, Naeem and Wright (2003, p. 567) state that "these (biodiversity-ecosystem function) studies have generally confirmed the importance of biodiversity to the functioning of ecosystems." Here, we show that one can obtain even greater productivity and hence ecosystem function simply by invading assemblages (fig. 5A). Thus, while our results suggest that diversity can provide an important "function" in resisting invasion, using yield as a benchmark for valuing the importance of diversity may be of limited utility since invasion can so dramatically influence yield.

The fact that invaders increase community biomass even in diverse assemblages suggests that native plants may not fill all available niches. Yet, the precise mechanisms that enable exotics such as knapweed to attain such prodigious productivity within invaded communities remain mostly a mystery. One possibility is that for exotics such as knapweed, differences in their phenology (timing of germination and flowering) and rooting morphology may enable them to tap into resources not available to natives. If this is the case, given the obvious advantages of doing so, it begs the broader question of why a given native has not evolved to exploit this unoccupied niche space. Perhaps because grassland communities in the intermountain West are relatively young (due to recent glaciation), there has been insufficient time for these assemblages to reach equilibrium.

While we have explored how two factors, native diversity and resource additions, might interact to influence invasibility/impact, it is important to recognize that these two processes can influence each other. For example, we previously found that resource availability declines with increasing native diversity (Maron and Marler 2007); ultimately, diversity may also decline with increasing resource additions if particular natives become competitively dominant under these conditions (Al-Mufti et al. 1977). Furthermore, although we did not find it in this study, diversity and resource addition might ultimately influence invader impact. Large invader impacts can result in feedbacks that drive down local native diversity and reduce resource availability. Quantifying the strength of these long-term feedbacks has not been accomplished but should be a major goal of future work.

\section{Acknowledgments}

We thank A. Agrawal, M. Ellis, E. Parsons, D. Pearson, T. D. Price, J. Williams, and two anonymous reviewers for helpful comments on the manuscript. S. Elmendorf provided input on statistical analyses. Thanks to J. Acker, S. Andresky, B. Barr, C. Brant, J. Brewer, B. Christians, L. Garrison, K. Goodwin, D. Hoopes, M. Johnson, A. Jones, S. LaFont, M. Maggio, K. Mareib, H. McKinney, L. R. McKinney, C. Meinershagen, S. Newman, A. Norris, T. 
Parchen, M. Pecora, C. Peña, R. Richter, A. Roberson, S. Rogge, B. Rosenzweig, J. Schmidt, Y. Shimizu, M. Valliant, Y. Wang, M. Wessner, and H. Whitely for fabulous field assistance. The Montana Conservation Corps and Prairie Keepers public outreach project volunteers helped set up experimental plots. This work was supported by a grant from the Montana Weed Trust fund and National Science Foundation grants DEB-0318719 to J.L.M. and M.M. and DEB-0614406 to J.L.M.

\section{Literature Cited}

Aerts, R., and F. Berendse. 1988. The effect of increased nutrient availability on vegetation dynamics in wet heathlands. Vegetatio 76:63-69.

Al-Mufti, M. M., C. L. Sydes, S. B. Furness, J. P. Grime, and S. R. Band. 1977. A quantitative analysis of shoot phenology and dominance in herbaceous vegetation. Journal of Ecology 65:759-791.

Bais, H. P., R. Vepachedu, S. Gilroy, R. M. Callaway, and J. M. Vivanco. 2003. Allelopathy and exotic plants: from genes to invasion. Science 301:1377-1380.

Burke, M. J. W., and J. P. Grime. 1996. An experimental study of plant community invasibility. Ecology 77:776-790.

Callaway, R. M., and E. T. Aschehoug. 2000. Invasive plants versus their new and old neighbors: a mechanism for exotic invasion. Science 290:521-523.

Callaway, R. M., and J. L. Maron. 2006. What have exotic invasions taught us over the past twenty years? Trends in Ecology \& Evolution 21:369-374.

Callaway, R. M., D. Cipollini, K. Barto, G. C. Thelen, S. G. Hallett, D. Prati, K. Stinson, and J. Klironomos. 1998. Novel weapons: invasive plant suppresses fungal mutualists in America but not in its native Europe. Ecology 89:1043-1055.

Case, T. J. 1990. Invasion resistance arises in strongly interacting species-rich model competitive systems. Proceedings of the National Academy of Sciences of the USA 87:9610-9614.

D'Antonio, C. M. 2000. Fire, plant invasions and global change. Pages 65-93 in H. A. Mooney and R. J. Hobbs, eds. Invasive species in a changing world. Island, Washington, DC.

D'Antonio, C. M., R. F. Hughes, M. Mack, D. Hitchcock, and P. Vitousek. 1998. Response of native species to the removal of nonnative grasses in a Hawaiian woodland. Journal of Vegetation Science 9:699-712.

Davis, M. A., and M. Pelsor. 2001. Experimental support for a resource-based mechanistic model of invasibility. Ecology Letters 4:421-428.

Davis, M. A., J. P. Grime, and K. Thompson. 2000. Fluctuating resources in plant communities: a general theory of invisibility. Journal of Ecology 88:528-534.

Dukes, J. S. 2002. Species composition and diversity affect grassland susceptibility and response to invasion. Ecological Applications 12: 602-617.

Dyer, A. R., and K. J. Rice. 1999. Effect of competition on resource availability and growth of a California bunchgrass. Ecology 80: 2697-2710.

Ehrenfeld, J. G. 2003. Effects of exotic plant invasions on soil nutrient cycling processes. Ecosystems 6:503-523.

Elton, C. S. 1958. The ecology of invasions. Methuen, London.

Evans, R. D., R. Rimer, L. Sperry, and J. Belnap. 2001. Exotic plant invasion alters nitrogen dynamics in an arid grassland. Ecological Applications 11:1301-1310.

Fargione, J. E., and D. Tilman. 2005. Diversity decreases invasion via both sampling and complementarity effects. Ecology Letters 8:604611.

Fargione, J., C. S. Brown, and D. Tilman. 2003. Community assembly and invasion: an experimental test of neutral versus niche processes. Proceedings of the National Academy of Sciences of the USA 100:8916-8920.

Gerlach, J. D., Jr. 2000. A model experimental system for predicting the invasion success and ecosystem impacts of non-indigenous summer-flowering annual plants in California's Central Valley grasslands and oak woodlands. PhD diss. University of California, Davis.

Hill, J. P., M. J. Germino, J. M. Wraith, B. E. Olson, and M. B. Swan. 2006. Advantages in water relations contribute to greater photosynthesis in Centaurea maculosa compared with established grasses. International Journal of Plant Sciences 167:269-277.

Hobbs, R. J., and L. F. Huenneke. 1992. Disturbance, diversity, and invasion: implications for conservation. Conservation Biology 6: 324-337.

Holmes, T. H., and K. J. Rice. 1996. Patterns and growth and soilwater utilization in some exotic annuals and native perennial bunchgrasses of California. Annals of Botany 78:233-243.

Hooper, D. U., F. S. Chapin III, J. J. Ewel, A. Hector, P. Inchausti, S. Lavorel, J. H. Lawton, et al. 2005. Effects of biodiversity on ecosystem functioning: a consensus of current knowledge. Ecological Monographs 75:3-35.

Houghton, J. T., Y. Ding, D. J. Griggs, M. Noguer, P. J. van der Linden, X. Dai, K. Maskell, and C. A. Johnson, eds. 2001. Climate change 2001: the scientific basis. Cambridge University Press, Cambridge.

Hubbell, S. P. 2001. The unified neutral theory of biodiversity and biogeography. Princeton University Press, Princeton, NJ.

Kennedy, T. A., S. Naeem, K. M. Howe, J. M. H. Knops, D. Tilman, and P. Reich. 2002. Biodiversity as a barrier to ecological invasion. Nature 417:636-638.

Knops, J. M. H., D. Tilman, N. M. Haddad, S. Naeem, C. E. Mitchell, J. Haarstad, M. E. Ritchie, et al. 1999. Effects of plant species richness on invasion dynamics, disease outbreaks, insect abundances and diversity. Ecology Letters 2:286-293.

Lavorel, S., A.-H. Prieur-Richard, and K. Grigulis. 1999. Invasibility and diversity of plant communities: from patterns to process. Diversity Distributions 5:41-49.

Levine, J. M. 2000. Species diversity and biological invasions: relating local processes to community patterns. Science 288:852-854.

Levine, J. M., M. Vilà, C. M. D’Antonio, J. S. Sukes, K. Garigulis, and S. Lavorel. 2003. Mechanisms underlying the impacts of exotic plant invasions. Proceedings of the Royal Society B: Biological Sciences 270:775-781.

Levine, J. M., P. B. Adler, and S. G. Yelenik. 2004. A meta-analysis of biotic resistance to exotic plant invasions. Ecology Letters 7: 975-989.

Loreau, M., and A. Hector. 2001. Partitioning selection and complementarity in biodiversity experiments. Nature 412:72-76.

MacArthur, R. H. 1970. Species-packing and competitive equilibrium for many species. Theoretical Population Biology 1:1-11.

Maron, J. L., and P. G. Connors. 1996. A native nitrogen-fixing shrub facilitates weed invasion. Oecologia (Berlin) 105:302-312.

Maron, J. L., and M. Marler. 2007. Native plant diversity resists 
invasion at both low and high resource levels. Ecology 88:26512661.

Milchunas, D. G., and W. K. Lauenroth. 1995. Inertia in plant community structure state changes after cessation of nutrient-enrichment stress. Ecological Applications 5:452-458.

Mueggler, W. F., and W. L. Stewart. 1980. Grassland and shrubland habitat types of western Montana. Intermountain Forest and Range Experimental Station, Ogden, UT.

Naeem, S. 2002. Ecosystem consequences of biodiversity loss: the evolution of a paradigm. Ecology 83:1537-1552.

Naeem, S., and J. P. Wright. 2003. Disentangling biodiversity effects on ecosystem functioning: deriving solutions to a seemingly insurmountable problem. Ecology Letters 6:567-579.

Naeem, S., J. M. H. Knops, D. Tilman, K. M. Howe, T. Kennedy, and S. Gale. 2000. Plant diversity increases resistance to invasion in the absence of covarying extrinsic factors. Oikos 91:97-108.

Ortega, Y. K., and D. E. Pearson. 2005. Weak vs. strong invaders of natural plant communities: assessing invisibility and impact. Ecological Applications 15:651-661.

Parker, I. M., D. Simberloff, W. M. Lonsdale, K. Goodell, M. Wonham, P. M. Kareiva, M. H. Williamson, et al. 1999. Impact: towards a framework for understanding the ecological effects of invaders. Biological Invasions 1:3-19.

Post, W. M., and S. I. Pimm. 1983. Community assembly and food web stability. Mathematical Biosciences 64:169-192.

Prieur-Richard, A.-H., S. Lavorel, K. Grigulis, and A. Dos Santos. 2000. Plant community dynamics and invasion by exotics: invasion of Mediterranean old fields by Conzya bonariensis and Conzya canadensis. Ecology Letters 2:412-422.

Rinella, M. J., M. L. Pokorny, and R. Rekaya. 2007. Grassland invader responses to realistic changes in native species richness. Ecological Applications 17:1824-1831.

Romanuk, T. N., and J. Kolasa. 2005. Resource limitation, biodiversity, and competitive effects interact to determine the invasibility of rock pool microcosms. Biological Invasions 7:711-722.

Sax, D. F., J. J. Stachowicz, and S. D. Gaines, eds. 2005. Species invasions: insights into ecology, evolution and biogeography. Sinauer, Sunderland, MA.

Sheley, R. L., and J. K. Petroff, eds. 1999. Biology and management of noxious rangeland weeds. Oregon State University Press, Corvallis.

Sheley, R. L., S. Kedzie-Webb, and B. D. Maxwell. 1999. Integrated weed management on rangeland. Pages 57-68 in R. L. Sheley and J. K. Petroff, eds. Biology and management of noxious rangeland weeds. Oregon State University Press, Corvallis.

Sperber, T. D., J. M. Wraith, and B. E. Olson. 2003. Soil physical properties associated with the invasive spotted knapweed and native grasses are similar. Plant and Soil 252:241-249.
Symstad, A. J. 2000. A test of the effects of functional group richness and composition on grassland invasibility. Ecology 81:99-109.

Thomsen, M. A., C. M. D'Antonio, K. B. Suttle, and W. P. Sousa. 2006. Ecological resistance, seed density and their interactions determine patterns of invasion in a California coastal grassland. Ecology Letters 9:160-170.

Tilman, D. 2004. A stochastic theory of resource competition, community assembly and invasions. Proceedings of the National Academy of Sciences of the USA 1010:10854-10861.

Tilman, D., J. Knops, P. Reich, M. Ritchie, and E. Sieman. 1997. The influence of functional diversity and composition on ecosystem processes. Science 277:1300-1302.

Tilman, D., P. B. Reich, J. Knops, D. Wedin, T. Mielke, and C. Lehman. 2001. Diversity and productivity in a long-term grassland experiment. Science 294:843-845.

van Ruijven, J., G. B. De Deyn, and F. Berendse. 2003. Diversity reduces invasibility in experimental plant communities: the role of plant species. Ecology Letters 6:910-918.

Vilà, M., J. D. Corbin, J. S. Dukes, J. Pino, and S. D. Smith. 2007. Pages 93-102 in J. Canadell, D. Pataki, and L. Pitelka, eds. Terrestrial ecosystems in a changing world. Springer, Berlin.

Vitousek, P. M., and L. R. Walker. 1989. Biological invasion by Myrica faya in Hawaii: plant demography, nitrogen fixation, and ecosystem effects. Ecological Monographs 59:247-265.

Vitousek, P. M., J. D. Aber, R. W. Howarth, G. E. Likens, P. A. Matson, D. W. Schindler, W. H. Schlesinger, and D. Tilman. 1997. Human alteration of the global nitrogen cycle: sources and consequences. Ecological Applications 7:737-750.

Walther, G.-R., E. Post, P. Convey, A. Menzel, C. Parmesan, T. J. C. Beebee, J.-M. Fromentin, O. Hoegh-Guldberg, and F. Bairlein. 2002. Ecological responses to recent climate change. Nature 416: 389-395.

Wardle, D. A. 2001. Experimental demonstration that plant diversity reduces invasibility: evidence of a biological mechanism or a consequence of sampling effect? Oikos 95:161-170.

Wedin, D. A., and D. Tilman. 1996. Influence of nitrogen loading and species composition on the carbon balance of grasslands. Science 274:1720-1723.

Zavaleta, E. 2000. Valuing ecosystem services lost to Tamarix invasion in the United States. Pages 261-300 in H. A. Mooney and R. J. Hobbs, eds. Invasive species in a changing world. Island, Washington, DC.

Zavaleta, E. S., and K. B. Hulvey. 2004. Realistic species losses disproportionately reduce grassland resistance to invaders. Science 306:1175-1177. 